\title{
Pengaruh Pengalaman, Profesionalisme, dan Etika Profesi Auditor Terhadap Penentuan Tingkat Materialitas
}

\author{
Irma Paramita Sofia ${ }^{1}$., Risha Trisantya Damayanti ${ }^{2}$ \\ ${ }^{1}$ Program Studi Akuntansi, Universitas Pembangunan Jaya \\ irma.paramita@upj.ac.id \\ ${ }^{2}$ Program Studi Akuntansi, Universitas Pembangunan Jaya \\ rishatrisantya@gmail.com
}

\begin{abstract}
Nowdays, the need of professional skills on independen public accountant is increased, public accountant profession is expected posses adequate competency to maintain their client and other financial report users trust. On performing general audit, auditor cannot give an absolute guarantee to their client or the reader that audited financial report is free from material misstatetement. This study is conducted to examine whether any influence of professionalism, experienced, and profession ethics to materiality level. This study used purposive sampling method, and the sampling of this research are 32 auditor from five firms in Jakarta and Tangerang. The data were collected through questions survey methods. The analysis technique are multiple regression. From the analyst there found partially experience and professional ethics have significant influence on consideration of materiality levels. The result of this studi shows that the professionalism don't have a partially effect to materiality level judgment.
\end{abstract}

Keywords : Professionalism, financial statement, materiality, auditor

\begin{abstract}
Abstrak : Semakin meluasnya kebutuhan jasa profesional akuntan publik sebagai pihak yang independen, profesi akuntan publik diharapkan memiliki kompetensi yang memadai untuk dapat mempertahankan kepercayaan klien dan para pemakai laporan keuangan lainnya. Dalam melaksanakan audit atas laporan keuangan, auditor tidak dapat memberikan jaminan mutlak bagi klien atau pemakai laporan keuangan lainnya bahwa laporan keuangan auditan adalah bebas dari salah saji material. Penelitian ini bertujuan untuk mengetahui apakah ada pengaruh profesionalisme, pengalaman, dan etika profesi terhadap pertimbangan tingkat materialitas, yaitu besarnya salah saji yang dapat mempengaruhi keputusan pemakai informasi. Jumlah sampel yang digunakan sebanyak 32 orang auditor dari 5 perusahaan, teknik penentuan sampel menggunakan purposive sampling. Pengumpulan data dilakukan dengan metode survey melalui penyebaran kuesioner. Teknik analisis yang digunakan adalah regresi berganda. Berdasarkan hasil pengujian secara parsial, pengalaman, etika profesi dan profesionalisme berpengaruh secara signifikan terhadap pertimbangan tingkat materialitas,
\end{abstract}

Kata Kunci : Profesionalisme, Laporan Keuangan, pengalaman, etika, dan materialitas

\section{PENDAHULUAN \\ Latar Belakang}

Pada era globalisasi saat ini dunia

usaha semakin lama semakin pesat perkembangannya. Hal ini memicu persaingan yang meningkat diantara pelaku pebisnis. Para pengelola usaha atau bisnis berlomba-lomba untuk meningkatkan pendapatannya masing-masing agar nantinya tetap dapat bertahan dalam 
menghadapi persaingan. Pemeriksaan laporan keuangan perusahaan adalah salah satu cara untuk mempertahankan bisnis mereka, jika perusahaan tidak mempertahankan bisnis mereka maka perusahaan akan kalah dalam persaingan atau akan bangkrut. Kegagalan Kantor Akuntan Publik (KAP) Arthur Anderson terhadap kliennya Enron tahun 2002 adalah salah satu kasus kegagalan audit berskala besar yang menjadi perhatian dunia. Dalam kasus Enron, kegagalan audit terjadi karena auditor terlibat dalam proses manipulasi keuangan. Selain itu terjadi beberapa kasus lainnya yang sempat menjadi perhatian publik di Indonesia, salah satunya adalah ketika Kantor akuntan publik mitra Ernst \& Young's (EY) di Indonesia, yakni KAP Purwantono, Suherman \& Surja sepakat membayar denda senilai US\$ 1 juta (sekitar Rp 13.3 miliar) kepada regulator Amerika Serikat serta memberikan sanksi kepada dua auditor mitra EY yang terlibat dalam audit pada tahun 2011, akibat divonis gagal melalukan audit laporan keuangan kliennya.

Pertimbangan (judgment) auditor akan sangat mempengaruhi, dalam hal materialitas, risiko, biaya, manfaat, ukuran, dan karakteristik populasi yang dapat mempengaruhi pertimbangan tingkat materialitas diantaranya adalah profesionalisme auditor (Utami, 2014). Pertimbangan auditor mengenai materialitas merupakan pertimbangan profesional dan dipengaruhi persepsi auditor atas kebutuhan orang yang memiliki pengetahuan memadai dan yang akan meletakkan kepercayaan pada laporan keuangan (Lestari, 2011).

Suryono (2013) mengemukakan seorang auditor dalam membuat laporan audit harus memiliki pengalaman yang cukup, karena pengalaman yang berbeda akan menyebabkan perbedaan dalam memandang dan menanggapi informasi yang diperoleh selama melakukan pemeriksaan dan juga dalam memberi kesimpulan audit terhadap obyek yang diperiksa yaitu berupa pemberian pendapat.
Pada saat auditor mempertimbangkan keputusan mengenai pendapat apa yang akan dinyatakan dalam laporan audit, material atau tidaknya informasi, mempengaruhi jenis pendapat yang akan diberikan oleh auditor.

\section{Perumusan Masalah}

Berdasarkan latar belakang di atas, maka ditentukan perumusan masalah sebagai berikut :

1. Apakah terdapat pengaruh profesionalisme terhadap penentuan tingkat materialitas?

2. Apakah terdapat pengaruh pengalaman auditor terhadap penentuan tingkat materialitas?

3. Apakah terdapat pengaruh etika profesi auditor sebelumnya terhadap penentuan tingkat materialitas?

4. Apakah terdapat pengaruh profesionalisme, pengalaman, dan etika profesi auditor terhadap penentuan tingkat materialitas?

\section{Tujuan}

Tujuan penelitian ini adalah untuk memperoleh bukti empiris mengenai pengaruh pengalaman auditor terhadap penentuan tingkat materialitas. Berdasarkan rumusan masalah, maka tujuan dari penelitian ini adalah untuk mengetahui :

1. Untuk mengetahui apakah profesionalisme auditor berpengaruh terhadap penentuan pertimbangan tingkat materialitas.

2. Untuk mengetahui apakah pengalaman auditor berpengaruh terhadap penentuan tingkat materialitas.

3. Untuk mengetahui apakah etika profesi auditor berpengaruh terhadap penentuan pertimbangan tingkat materialitas.

4. Untuk mengetahui apakah profesionalisme, pengalaman dan etika profesi auditor berpengaruh terhadap penentuan tingkat materialitas. 


\section{Sistematika Penulisan}

\section{Pendahuluan}

Terdiri dari latar belakang penelitian, rumusan masalah, tujuan penelitian, manfaat yang diambil dari penelitian dan dibagian akhir diuraikan sistematika penyajian Laporan Penelitian.

\section{Tinjauan Pustaka}

Pada bagian ini dijelaskan teoriteori serta pustaka yang dipakai pada waktu penelitian. Teori yang dipakai dalam penelitian diambil melalui buku literatur dan jurnal. Teori yang dibahas meliputi teori tentang pengalaman, profesionalisme, dan opini auditor sebelumnya terhadap penentuan tingkat materialitas akuntan publik.

\section{Metodologi Penelitian}

Penjabaran mengenai permasalahan dalam penelitian alat dan metode yang digunakan untuk melakukan perencanaan yang berisi metode penelitian yang akan digunakan, metode penelitian, objek penelitian, variabel penelitian, pengumpulan data, dan tahapan penelitian.

\section{Analisa permasalahan dan Hasil Penelitian}

$\mathrm{Bab}$ ini berisi analisis dan interpretasi data berdasarkan alat dan teknik yang digunakan serta menjelaskan hasil analisis data dengan teori terkait.

\section{Simpulan}

Bagian ini meliputi kesimpulan yang berasal dari hasil analisis pada bagian sebelumnya. Kesimpulan diperlukan untuk menjawab perumusan masalah yang tercantum pada Bagian pertama.

\section{KAJIAN PUSTAKA}

Menurut pengertian umum, seseorang dikatakan profesional jika memenuhi tiga kriteria, yaitu mempunyai keahlian untuk melaksanakan tugas sesuai dengan bidangnya, melaksanakan suatu tugas atau profesi dengan menetapkan standar baku di bidang profesi yang bersangkutan dan menjalankan tugas profesinya dengan mematuhi Etika Profesi yang telah ditetapkan (Nasution, 2015). Profesionalisme auditor merupakan sikap dan perilaku seorang auditor dalam menjalankan profesinya dengan kesungguhan dan tanggung jawab agar mencapai kinerja tugas sebagaimana yang diatur dalam organisasi profesi, yang meliputi pengabdian pada profesi, kewajiban sosial, kemandirian, kepercayaan terhadap peraturan profesi dan hubungan dengan rekan seprofesi (Febrianty, 2012).

Menurut Alvina (2010), seorang akuntan publik yang profesional akan mempertimbangkan material atau tidaknya informasi dengan tepat, karena hal ini berhubungan dengan jenis pendapat yang akan diberikan. Sehingga auditor yang semakin profesional dapat menentukan tingkat materialitas dalam laporan keuangan dengan semakin tepat.

Hal itu sejalan dengan penelitian Adi (2012) yang menyatakan auditor yang mempunyai pengalaman yang berbeda, akan berbeda pula dalam memandang dan menanggapi informasi yang diperoleh selama melakukan pemeriksaan dan juga di dalam memberikan kesimpulan audit terhadap objek yang diperiksa berupa pemberian pendapat dan ketika mempertimbangkan keputusan mengenai pendapat apa yang akan dinyatakan dalam laporan audit, material atau tidaknya informasi, mempengaruhi jenis pendapat yang akan diberikan oleh auditor.

Etika profesi akuntan di Indonesia diatur dalam Kode Etik Akuntan Indonesia. Kode etik ini mengikat para anggota IAI di satu sisi dan dapat dipergunakan oleh akuntan lainnya yang bukan atau belum menjadi anggota IAI di sisi lainnya (Nasution, 2015).

\section{Tingkat materialitas}

Menurut Febryanti

materialitas adalah besarnya suatu informasi akuntansi yang apabila terjadi penghilangan atau salah saji, dilihat dari 
keadaan yang melingkupinya, mungkin dapat merubah atau mempengaruhi pertimbangan orang yang meletakkan kepercayaan atas informasi tersebut. Hal ini dapat didukung dengan memperhitungkan suatu keadaan yang melingkupinya.

Definisi materialitas mengharuskan auditor untuk mempertimbangkan baik keadaan yang berkaitan dengan entitas dan kebutuhan informasi pihak yang akan meletakkan kepercayaan atas laporan keuangan auditan (Nasution, 2013)

Idawati (2016) menyatakan bahwa materialitas adalah besarnya nilai yang dihilangkan atau salah saji informasi akuntansi, yang dilihat dari keadaan yang melingkupi, dapat mengakibatkan perubahan atau pengaruh terhadap pertimbangan orang yang meletakan kepercayaan terhadap informasi tersebut karena adanya penghilangan atau salah saji itu. Suatu pertimbangan materialitas juga diperlukan untuk menentukan jumlah bukti yang harus dikumpulkan atau kecukupan bukti pada saat pengauditan. Jika pada saat pengauditan terdapat bukti audit yang cukup maka auditor dapat memberikan pendapat atas laporan keuangan yang diaudit tersebut.

Pertimbangan tingkat materialitas diukur dengan indikator yang mengacu pada penelitian Kusuma (2012) indikator tersebut adalah sebagai berikut:

1. Seberapa penting tingkat materialitas

2. Pengetahuan tentang tingkat materialitas

3. Risiko audit

4. Tingkat materialitas antar perusahaan

5. Urutan tingkat materialitas dalam rencana audit

\section{Financial Accounting Standard} Board (FASB) menjelaskan konsep materialitas sebagai penghilang atau salah saji suatu item dalam laporan keuangan adalah material jika, dalam keadaan yang tertentu, besarnya item tersebut mungkin menyebabkan pertimbangan yang reasonable berdasarkan laporan keuangan tersebut akan berubah atau terpengaruh oleh adanya pencantuman atau peniadaan informasi akuntansi tersebut.

\section{Penelitian Terdahulu}

Beberapa penelitian telah membahas mengenai pengaruh profesionalisme, pengalaman dan etika profesi auditor terhadap penentuan tingkat materialitas sebagai berikut:

Lestari (2011) melakukan penelitian ini dengan tujuan utamanya untuk membuktikan pengaruh profesionalisme, etika, pengalaman, pengetahuan dan kualitas audit terhadap pertimbangan tingkat materialitas akuntan publik. Sampel Kantor Akuntan Publik di wilayah Kota Surabaya dengan jumlah sebanyak 45 KAP. Penelitian ini memperoleh data dengan menyebar kuesioner dan kemudian menggunakan skala likert. Metode statistik yang digunakan untuk menguji hipotesis adalah linear berganda. Hasil dari penelitian menunjukkan bahwa profesionalisme, etika profesi, pengalaman, pengetahuan mendeteksi kekeliruan dan kualitas audit auditor berpengaruh secara positif terhadap pertimbangan tingkat materialitas.

Ekawati (2013) melakukan penelitian dengan tujuan untuk mendapatkan bukti empiris tentang pengaruh profesionalisme, pengalaman kerja dan tingkat pendidikan auditor terhadap pertimbangan tingkat materialitas (studi empiris pada Kantor Akuntan Publik di Wilayah Bali). Populasi dalam penelitian ini adalah seluruh auditor yang bekerja pada kantor akuntan publik di wilayah Bali yang tergabung dalam Ikatan Akuntan Indonesia Kompartemen Akuntan Publik. Hasil dari penelitian menunjukkan bahwa profesionalisme, pengalaman kerja dan tingkat pendidikan auditor berpengaruh positif dan signifikan terhadap pertimbangan tingkat materialitas. 
Utami (2014), meneliti tentang pengaruh profesioanlisme auditor, etika profesi dan pengalaman auditor terhadap pertimbangan tingkat materialitas dengan kredibilitas klien sebagai pemoderasi. Penelitian ini memberikan kesimpulan, yaitu: semakin tinggi tingkat profesionalisme yang dimiliki seorang auditor, maka pertimbangan dalam memutuskan pemenuhan keinginan klien akan semakin ketat atau akan semakin tidak mudah dalam rangka memenuhi keinginan klien.

\section{Perbedaan Penelitian Saat Ini dengan Penelitian Terdahulu}

Terdapat perbedaan pada penelitian terdahulu dengan penelitian saat ini, antara lain:

\section{Sampel}

Terdapat perbedaan sampel yang dilakukan oleh penelitian terdahulu dengan penelitian saat ini. Pada penelitian saat ini sampel yang digunakan berasal dari salah satu Kantor Akuntan Publik big 4 yaitu Kantor Akuntan Publik Prwanto, Sungkoro \& Surja. Selain itu peneliti juga menggunakan sampel dari KJPP Maulana Andesta \& Rekan, PT Pos Indonesia, Tbk, PT Jaya Konstruksi Manggala Pratama, Tbk, dan Yayasan Pendidikan Jaya. Sampel yang dituju dalam penelitian saat ini yaitu seorang auditor yang sudah memiliki pengalaman sebagai auditor minimal 2 tahun.

\section{Waktu}

Periode penelitian saat ini dilakukan pada tahun 2017. Sehingga dalam penelitian ini mendapatkan hasil kuisioner yang terbaru dari penelitian terdahulu.

\section{Indikator}

Dalam penelitian pada kali ini akan menambah suatu indikator pada variabel pengalaman auditor. Dimana pada variabel pengalaman akan ditambah indikator jenjang karir, keahlian, kemampuan mendeteksi kekeliruan, kemampuan menyelesaikan masalah dam pembuatan judgement.

\section{Responden}

Pada penelitian kali ini penulis akan menyebarkan kuesioner kepada auditor internal dan auditor eksternal. Hal ini dapat bisa mengetahui apakah terdapat perbedaan jawaban antara auditor internal dan auditor eksternal.

\section{METODOLOGI PENELITIAN Objek Penelitian}

Dalam penulisan skripsi ini, objek penelitian variabel bebas (independen) adalah profesionalisme, pengalaman dan etika profesi. Variabel terikat (dependen) adalah tingkat materilitas. Adapun penentuan pemilihan sampel dilakukan dengan menggunakan metode purposive sampling, yaitu teknik pengambilan sampel dengan dasar pada pertimbangan yang merupakan tipe pemilihan sampel secara acak dimana informasinya diperoleh dengan pertimbangan tertentu. Pertimbangan tersebut adalah:

1. Sasaran sampel adalah auditor yang bekerja pada Kantor Akuntan Publik atau Perusahaan yang berada di Jakarta dan Tangerang Selatan.

2. Auditor yang sudah mempunyai status minimal auditor senior (memiliki masa kerja lebih dari 2 tahun).

Teknik pemilihan sampel dengan menggunakan metode purposive sampling ini dilakukan mengingat pertimbangan tingkat materialitas tidak dapat dilakukan oleh semua Auditor akan tetap hanya dapat dilakukan oleh Auditor yang sudah berpengalaman dalam melakukan audit (memiliki masa kerja lebih dari 2 tahun).

Tabel 1. Variabel Penelitian Operasional Variabel

\begin{tabular}{|c|c|c|}
\hline Variabel & Dimensi & Indikator \\
\hline \multirow{5}{*}{$\begin{array}{l}\text { Pengalaman } \\
\text { Auditor } \\
\left(\mathrm{X}_{1}\right) \text {. }\end{array}$} & \multirow{5}{*}{$\begin{array}{l}\text { Lamanya auditor } \\
\text { bekerja di bidang } \\
\text { audit dan banyaknya } \\
\text { penugasan audit yang } \\
\text { pernah ditangani. }\end{array}$} & 1. Lama Bekerja \\
\hline & & $\begin{array}{l}\text { 2. Banyaknya } \\
\text { penugasan }\end{array}$ \\
\hline & & 3. Jenjang karir \\
\hline & & Keahlian \\
\hline & & $\begin{array}{ll}\text { 5. } & \text { Kemampuan } \\
\text { mendeteksi } \\
\text { kekeliruan }\end{array}$ \\
\hline
\end{tabular}




\begin{tabular}{|c|c|c|}
\hline Variabel & Dimensi & Indikator \\
\hline & & $\begin{array}{ll}6 . & \begin{array}{l}\text { Kemampuan } \\
\text { menyelesaikan } \\
\text { masalah }\end{array} \\
\end{array}$ \\
\hline & & $\begin{array}{ll}7 . & \text { Pembuatan } \\
\text { Judgement }\end{array}$ \\
\hline \multirow[t]{5}{*}{$\begin{array}{l}\text { Profesionali } \\
\text { sme }\left(\mathrm{X}_{2}\right)\end{array}$} & \multirow{5}{*}{$\begin{array}{lr}\text { Afiliasi } & \text { dengan } \\
\text { komunitas, } & \\
\text { kepentingan } & \text { sosial, } \\
\text { dedikasi } & \text { terhadap } \\
\text { pekerjaan, keyakinan } \\
\text { terhadap peraturan } \\
\text { profesi, tuntutan } \\
\text { untuk mandiri. }\end{array}$} & $\begin{array}{ll}\text { 1. } & \text { Pengabdian } \\
\text { pada Profesi }\end{array}$ \\
\hline & & $\begin{array}{ll}\text { 2. } & \text { Kewajiban } \\
& \text { Sosial } \\
\end{array}$ \\
\hline & & 3. Kemandirian \\
\hline & & $\begin{array}{ll}\text { 4. } & \text { Keyakinan } \\
\text { Terhadap } \\
\text { Profesi }\end{array}$ \\
\hline & & $\begin{array}{ll}\text { 5. } & \text { Hubungan } \\
\text { dengan Sesama } \\
\text { Rekan } \\
\text { Seprofesi } \\
\end{array}$ \\
\hline \multirow[t]{8}{*}{$\begin{array}{l}\text { Etika } \\
\text { Profesi }\left(\mathrm{X}_{3}\right) .\end{array}$} & & $\begin{array}{ll}\text { 1. } & \text { Tanggung } \\
\text { Jawab }\end{array}$ \\
\hline & & $\begin{array}{ll}\text { 2. } & \text { Kepentingan } \\
& \text { Publik }\end{array}$ \\
\hline & & 3. $\quad$ Integritas \\
\hline & & 4. $\quad$ Objektivitas \\
\hline & & $\begin{array}{ll}\text { 5. } & \text { Kompetensi } \\
\text { dan Kehati- } \\
\text { hatian }\end{array}$ \\
\hline & & 6. $\quad$ Kerahasiaan \\
\hline & & $\begin{array}{ll}\text { 7. } & \text { Perilaku } \\
& \text { Profesional }\end{array}$ \\
\hline & & 8. $\quad$ Standar Teknis \\
\hline \multirow[t]{5}{*}{$\begin{array}{l}\text { Tingkat } \\
\text { Materialitas } \\
\text { (Y). }\end{array}$} & \multirow{5}{*}{ 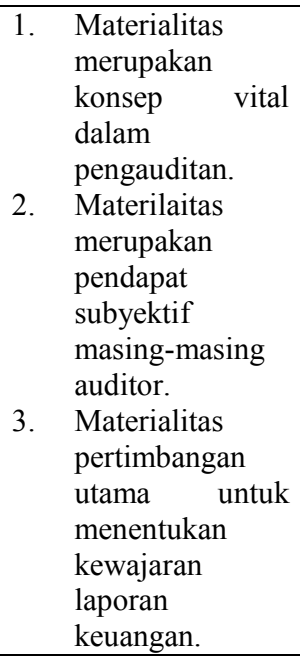 } & $\begin{array}{l}\text { 1. Sebarapa } \\
\text { penting tingkat } \\
\text { materialitas. }\end{array}$ \\
\hline & & $\begin{array}{ll}\text { 2. } & \text { Pengetahuan } \\
\text { mengenai } \\
\text { tingkat } \\
\text { materialitas. }\end{array}$ \\
\hline & & 3. $\quad$ Risiko audit. \\
\hline & & $\begin{array}{ll}\text { 4. } & \text { Tingkat } \\
\text { materialitas } \\
\text { antar } \\
\text { perusahaan. } \\
\end{array}$ \\
\hline & & $\begin{array}{l}\text { 5. Urutan tingkat } \\
\text { materialitas } \\
\text { dalam rencana } \\
\text { audit. }\end{array}$ \\
\hline
\end{tabular}

\section{HASIL PENELITIAN DAN ANALISIS Uji Validitas}

Setelah melakukan Uji Validitas terdapat pertanyaan yang tidak valid. Pada Variabel Profesionalisme terdapat 2 pertanyan yang tidak valid yaitu pada pertanyaan X1.3 dan X1.8. Pertanyaan yang tidak valid selanjutnya pada variabel pengalaman adalah pertanyaan X2.8. Selain itu juga terdapat pertanyaan yang tidak valid variabel tingkat materialitas di pertanyaan Y1.19 dan Y1.22.

\section{Uji Reliabilitas}

Hasil dari uji reliabilitas menunjukkan bahwa Cronbach's Alpha untuk semua pernyataan variabel profesionalisme, pengalaman, etika profesi dan tingkat materialitas $>0,60$. Nilai masing- masing variabel yaitu $0.793,0.865$, 0.920 dan 0.902. Maka dapat disimpulkan dari nilai tersebut bahwa variabel profesionalisme, pengalaman, etika profesi dan tingkat materialitas pada kuesioner peneliti bersifat reliabel.

\section{Uji Normalitas}

Hasil uji normalitas dapat dilihat nilai Kolmogorov-smirnov test masingmaisng varibel yaitu variabel profesionalisme sebesar 0,200 , variabel pengalaman sebesar 0,200, variabel etika profesi sebesar 0,165 dan variabel tingkat materialitas sebesar 0,074. Pada nilai tiap masing-masing varibael $>0.05$ maka dapat dikatakan bahwa data yang diolah bersifat normal atau tidak terjadi masalah pada uji normalitas.

\section{Uji Autokorelasi}

Berdasarkan pada output diatas bahwa nilai Asymp. Sig. (2-tailed) sebesar 0.208. nilai tersebut diartikan bahwa Asymp. Sig. (2-tailed) lebih besar $>$ dari 0.05, maka dapat disimpulkan bahwa tidak terjadi gejala atau tidak terjadi autokorelasi.

\section{Uji Multikolinearitas}

Hasil dari Uji Multikolinearitas menunjukkan bahwa nilai pada Tolerance masing-masing variabel $>0,10$ yaitu nilainya variabel profesionalisme 0,366 , variabel pengalaman 0,453 dan variabel etika profesi 0,571. Sedangkan pada kolom nilai VIF masing-masing variabel bernilai $<$ 10,00. Nilai dari tiap masing-masing varibel adalah variabel profesionalisme 2,736, variabel pengalaman 2,206 dan variabel etika profesi sebesar 1,751. Dari 
hasil diatas dapat disimpulkan bahwa tidak terjadi uji multikolinearitas.

\section{Uji Heteroskedastisitas}

Hasil dari Uji Heteroskedastisitas menunjukkan nilai signifikansi masingmasing variabel yaitu variabel profesionalisme $\quad 0,193, \quad$ variabel pengalaman 0,197 dan variabel etika profesi 0,569 . Nilai signifikansi tersebut nilainya $>0,05$. Maka dapat diartikan bahwa tidak terjadi heteroskedastisitas.

\section{Uji Koefisien Determinasi}

Hasil dari Uji Koefisien Determinasi dapat dilihat nilai koefisien determinasi ( $\mathrm{R}$ square) sebesar 0.623 adalah pengkuadratan dari koefisien korelasi atau $\mathrm{R}$, yaitu $0.789 \times 0.789=0.623$. Besarnya angka koefisien determinasi ( $\mathrm{R}$ square) 0.623 sama dengan $62.3 \%$. Angka tersebut artinya adalah profesionalisme, pengalaman dan etika profesi berpengaruh terhadap tingkat materialitas sebesar $62.3 \%$. Sedangkan sisanya $(100 \%-62.3 \%$ $=37.7 \%$ ) dipengaruhi oleh variabel lain diluar model regresi ini.

\section{Persamaan Linear Berganda}

$\mathrm{Y}=3.946+0.084 \mathrm{X}_{1}+0.728 \mathrm{X}_{2}+0.571 \mathrm{X}_{3+\mathrm{e}}$

Berikut ini adalah penjelasan dari persamaan regresi berganda sebagai berikut:

Baik konstanta maupun koefisien variabel-variabel independen memiliki nilai positif. Hal ini menandakan bahwa persamaan regresi berganda tersebut memiliki hubungan yang searah. Yang artinya adalah penentuan tingkat materialitas akan semakin meningkat seiring dengan meningkatnya profesionalisme, pengalaman dan etika profesi auditor.

Untuk koefisien regresi sebesar 0.084 untuk variabel profesionalisme (X1), sebesar 0.728 untuk variabel pengalaman (X2) dan 0.571 untuk variabel etika profesi (X3). Hal ini menunjukkan pengaruh masing-masing variabel tersebut terhadap variabel penentuan tingkat materialitas (Y1).

Jika dilihat nilai konstanta sebesar 3.946 berarti bahwa seorang auditor tetap dapat meningkatkan kemampuan dalam hal penentuan tingkat materialitasnya sebesar nilai konstantanya meskipun variabel independennya bernilai nol.

\section{Uji F}

Berdasarkan hasil perhitungan diperoleh $\mathrm{F}$ hitung sebesar 15.435 sedangkan $\mathrm{F}$ tabel dengan tingkat signifikansi $5 \%$, jumlah variabel bebas 3 , variabel terikat 1 dan 32 jumlah responden diperoleh $F$ tabel sebesar 2.93. Sehingga dapat dilihat bahwa nilai $\mathrm{F}$ hitung $>\mathrm{F}$ tabel, berarti dapat ditarik kesimpulan bahwa profesionalisme, pengalaman dan etika profesi secara bersama-sama berpengaruh terhadap penentuan tingkat materialitas auditor.

\section{Uji t}

Berdasarkan hasil perhitungan dapat mengetahui pengaruh masing-masing variabel bebas terhadap variabel terikat yaitu antara profesionalisme terhadap penentuan tingkat materialitas, pengalaman terhadap penentuan tingkat materialitas dan etika profesi terhadap penentuan tingkat materialitas. Dalam penelitian ini maka dilakukan pengujian terhadap koefisien regresi yaitu dengan pengujian sebagai berikut:

1. Pengujian $t$ hitung koefisien Profesionalisme.

a. Nilai $t$ hitung untuk koefisien regresinya adalah 0.269 .

b. Untuk nilai $t$ tabel untuk $t(0.05: 32)$ adalah 1.694.

c. Dari hasil perbandingan antara $t$ hitung dengan $\mathrm{t}$ tabel, maka dapat dilihat bahwa nilai $0.269<1.694$ sehingga dapat disimpulkan bahwa tidak terdapat pengaruh yang signifikan dari Profesionalisme terhadap penentuan tingkat materialitas. 
2. Pengujian $\mathrm{t}$ hitung koefisien Pengalaman.

a. Nilai $t$ hitung untuk koefisien regresinya adalah 2.814 .

b. Untuk nilai t tabel untuk $\mathrm{t}(0.05: 32)$ adalah 1.694.

c. Dari hasil perbandingan antara t hitung dengan $\mathrm{t}$ tabel, maka dapat dilihat bahwa nilai $2.814>1.694$ sehingga dapat disimpulkan bahwa terdapat pengaruh yang signifikan dari Pengalaman terhadap penentuan tingkat materialitas. Dari probabilitas valuenya juga dapat dilihat bahwa $p$ value sebesar 0.009 yang artinya lebih kecil dari 0.05 berarti dalam hal ini kesimpulan yang diambil sama, yaitu terdapat pengaruh yang signifikan dari Pengalaman terhadap penentuan tingkat materialitas.

3. Pengujian $t$ hitung koefisien Etika Profesi.

a. Nilai $t$ hitung untuk koefisien regresinya adalah 2.389 .

b. Untuk nilai $\mathrm{t}$ tabel untuk $\mathrm{t}(0.05: 32)$ adalah 1.694.

c. Dari hasil perbandingan antara $t$ hitung dengan $\mathrm{t}$ tabel, maka dapat dilihat bahwa nilai $2.389<1.694$ sehingga dapat disimpulkan bahwa terdapat pengaruh yang signifikan dari Etika Profesi terhadap penentuan tingkat materialitas. Dari probabilitas valuenya juga dapat dilihat bahwa $p$ value sebesar 0.024 yang artinya lebih kecil dari 0.05 berarti dalam hal ini kesimpulan yang diambil sama, yaitu terdapat pengaruh yang signifikan dari Etika Profesi terhadap penentuan tingkat materialitas.

\section{Pembahasan}

\section{a. Profesionalisme terhadap penentuan tingkat materialitas}

Dari penelitian yang telah dilakukan diperoleh hasil bahwa Profesionalisme Auditor tidak berpengaruh signifikansi terhadap penentuan tingkat materialitas. Hal ini berdasarkan pengujian dengan indikator pengabdian pada profesi, kewajiban sosial, kemandirian, keyakinan terhadap profesi dan hubungan dengan sesama rekan seprofesi. Berdasarkan dari pengujian $\mathrm{t}$ (parsial) nilainya adalah 0.269 $<1.694$ atau dilihat dari hasil nilai signifikansinya $0.790>0.05$, maka dapat ditarik kesimpulan bahwa hipotesis ditolak. Sehingga Profesionalisme tidak berpengaruh signifikan terhadap penentuan Tingkat materialitas. Jika dilihat dari nilai signifikansinya sebesar 0.790 itu dapat diartakan bahwa persentase pada penelitian ini memiliki kebenaran sebesar $21 \%$ dimana kemungkinan terjadi kesalahannya sebesar $79 \%$.

Pada penelitian ini profesionalisme tidak berpengaruh signifikan terhadap penentuan tingkat materialitas dikarenakan dari indikator profesionalisme yaitu pengabdian pada profesi, kewajiban sosial, kemandirian, keyakinan terhadap profesi dan hubungan dengan sesama profesi ada beberapa indikator yang tidak berpengaruh terhadap penentuan tingkat materialitas. Sehingga menyebabkan variabel profesionalisme itu sendiri tidak berpengaruh terhadap tingkat materialitas.

Hal ini sejalan dengan penelitian Basri (2011) menyatakan bahwa secara parsial tidak semua variabel profesionalisme berpengaruh secara signifikan terhadap pertimbangan tingkat materialitas auditor kecuali variabel kemandirian.

\section{b. Pengalaman terhadap penentuan tingkat materialitas}

Dari hasil pengujian dalam penelitian sebelumnya bahwa pengalaman auditor berpengaruh signifikansi terhadap penentuan tingkat materialitas. Hal ini berdasarkan pengujian dengan indikator lamanya bekerja sebagai auditor, banyaknya tugas pemeriksaan, jenjang karir, keahlian, kemampuan mendeteksi kekeliruan, kemampuan menyelesaikan masalah dan pembuatan judgement. Berdasarkan dari pengujian $\mathrm{t}$ (parsial) nilainya adalah $2.814>1.694$ atau dilihat 
dari hasil nilai signifikansinya $0.009>0.05$, maka dapat ditarik kesimpulan bahwa hipotesis diterima. Sehingga pengalaman berpengaruh signifikan terhadap penentuan tingkat materialitas. Jika dilihat dari nilai signifikansinya sebesar 0.009 itu dapat diartakan bahwa persentase pada penelitian ini memiliki kebenaran sebesar 99.1\% dimana kemungkinan terjadi kesalahannya sebesar $0.9 \%$. Berikut ini adalah persamaan regresi linier berganda yang ditulis berdasarkan secara parsial:

$$
\mathrm{Y}=3.946+0.728\left(\mathrm{X}_{2}\right)+\mathrm{e}
$$

Dilihat dari persamaan linier berganda diatas nilai konstanta adalah 3.946 artinya nilai tingkat materialitas akan berinlai 3.946 apabila pengalaman bernilai nol atau konstan. Lalu nilai dari $\beta_{1} X_{3}$ adalah sebesar 0.728 artinya apabila pengalaman naik satu maka nilai tingkat materialitas akan naik sebesar 0.728 .

\section{c. Etika profesi terhadap penentuan tingkat materialitas}

Hasil signifikansi yang diperoleh adalah $0.790>0.05$ dan nilai koefisien regresi determinasi (Adjusted $R$ Square) sebesar 0.583. Berdasarkan dari pengujian $\mathrm{t}$ (parsial) nilainya adalah $2.389<1.694$ atau dilihat dari hasil nilai signifikansinya 0.024 $>0.05$, maka dapat ditarik kesimpulan bahwa hipotesis diterima. Sehingga Etika Profesi berpengaruh signifikan terhadap penentuan tingkat materialitas. Jika dilihat dari nilai signifikansinya sebesar 0.024 itu dapat diartakan bahwa persentase pada penelitian ini memiliki kebenaran sebesar 97.6\% dimana kemungkinan terjadi kesalahannya sebesar $2.4 \%$. Berikut ini adalah persamaan regresi linier berganda yang ditulis berdasarkan secara parsial:

$$
\mathrm{Y}=3.946+0.571\left(\mathrm{X}_{3}\right)+\mathrm{e}
$$

Dari persamaan linear berganda diatas bahwa nilai konstanta sebesar 3.946 artinya nilai tingkat materialitas akan berinlai 3.946 apabila etika profesi bernilai nol atau konstan. Sedangkan nilai dari $\beta_{1} X_{3}$ sebesar 0.571 artinya apabila etika profesi naik satu maka nilai tingkat materialitas akan naik sebesar 0.571 .

\section{SIMPULAN}

Berdasarkan data yang telah dikumpulkan dan hasil pengujian yang telah dilakukan, maka dapat diambil kesimpulan sebagai berikut:

1. Profesionalisme tidak berpengaruh terhadap penentuan tingkat materialitas.

2. Pengalaman dan etika profesi berpengaruh signifikan terhadap penentuan tingkat materialitas.

3. Secara simultan, profesionalisme, pengalaman dan etika profesi berpengaruh signifikan terhadap penetuan tingkat materialitas.

\section{DAFTAR PUSTAKA}

1. Adi, Adia Prabowo, Pengaruh Profesionalisme Auditor, Etika Profesi, dan Pengalaman Auditor terhadap Pertimbangan Tingkat materialitas. Jurnal Kajian dan Pendidikan Akuntansi Indonesia. 1(3), 2012.

2. Alvina, Suryawana, Analisis hubungan antara profesionalisme auditor dengan pertimbangan tingkat materialitas dalam proses pengauditan laporan keuangan. Skripsi .Universitas Udayana, 2012.

3. Febrianty, Pengaruh Profesionalisme Auditor Terhadap Pertimbangan Tingkat materialitas Audit Atas Laporan Keuangan. Jurnal Ekonomi dan Informasi AkuntansiVol. 2. No. 2, 2012.

4. Financial Accounting Standard Board (FASB)

5. Idawati Wiwid dan Roswita, Pengaruh Independensi, Kompetensi dan Profesionalisme Auditor terhadap Pertimbangan Tingkat materialitas dalam Pemeriksaan Laporan Keuangan. Jurnal Akuntansi/Volume XX, No. 01, Januari 2016: 16-32, 2012.

6. Kusuma, Novanda Friska Bayu Aji, Pengaruh Profesionalisme Auditor, Etika Profesi dan Pengalaman Auditor terhadap Pertimbangan Tingkat 
Materialitas.Fakultas Ekonomi Universitas Negeri Yogyakarta. 2012.

7. Lestari, Anindy Mugia, Pengaruh Profesionalisme, Etika, Pengalaman, Pengetahuan dan Kualitas Audit Terhadap Pertimbangan Tingkat materialitas Akuntan Publik. Jurnal Akuntansi UNESA, Vol 3 No. 2, 2012.

8. Nasution, Emmy Suryani, Pengaruh Profesionalisme Auditor, Etika Profesi dan Pengalaman Auditor Terhadap Pertimbangan Tingkat materialitas. Jurnal Ilmiah Dunia Ilmu, Vol 1 No. 1, 2012.

9. Suryono, Eko, The Effects of Independence, Experience and Accountability to the Audit Quality. Lecturer at Departement of Accounting, Faculty of Economics and Business, University of Jenderal Soedirman, Purwokerto, Indonesia, . 2013.

10. Utami, Galeh, Pengaruh Profesionalisme Auditor, Etika Profesi dan Pengalaman Auditor Terhadap Pertimbangan Tingkat materialitas dengan Kredibilitas Klien sebagai Pemoderasi. Jurnal Nominal, Vol 1 No. $1, .2014$. 